\title{
Three-Capital Approach to the Study of Young People who Excel in Vocational Occupations: A Case of WorldSkills Competitors and Entrepreneurship
}

\author{
Maia Chankseliani* \\ University of Oxford \\ Department of Education \\ 15 Norham Gardens, OX26PY, Oxford, United Kingdom \\ E-mail: maia.chankseliani@education.ox.ac.uk \\ Susan James Relly \\ University of Oxford \\ Department of Education \\ 15 Norham Gardens, OX26PY, Oxford, United Kingdom \\ E-mail: susan.jamesrelly@education.ox.ac.uk \\ * Corresponding author
}

Received: 28 September 2015; Accepted: 21 December 2015; Published online: 30 April 2016

\begin{abstract}
This paper examines the entrepreneurial inclinations of young people who achieved excellence in vocational occupations. We propose a three-capital approach to the study of entrepreneurship. Relying on the existing theories and original qualitative and quantitative data analyses, findings from interviews with 30 entrepreneurial and 10 non-entrepreneurial WorldSkills competitors show that psychological capital, social capital and human capital can be combined to explore how young people who excel in vocational occupations develop entrepreneurial mindsets. We show that training for and participation in the largest vocational skills event globally - WorldSkills competition - develops selected aspects of three capitals. However, we also discover that the entrepreneurial motivation precedes competitors' involvement with WorldSkills.
\end{abstract}

Keywords: Case study, semi-structured interview, vocational education and training, entrepreneurship, psychological capital, social capital, human capital

\section{Bibliographical notes:}

Dr Maia Chankseliani is Associate Professor at the Department of Education at the University of Oxford, UK. Her research interests focus on post-compulsory education, apprenticeships, private training provision.

Dr Susan James Relly is Associate Professor at the Department of Education at the University of Oxford, UK. Her research interests focus on vocational education and training policy, apprenticeship and workplace learning. 


\section{Introduction}

In the UK, entrepreneurship is popular, especially amongst young people. In 2011, $77 \%$ of 11 to 18 -year-olds indicated that they wanted to start their own business, with an even split between the genders (startups.co.uk, 2011). According to the most recent statistics, $14 \%$ of the UK workforce is self-employed (ONS, 2013). In addition, the Global Entrepreneurship and Development Institute (GEDI) recognised the UK as the most entrepreneurial economy in Europe and the fourth most entrepreneurial economy in the world (GEDI, 2014). However, and at the same time, the Special Eurobarometer indicates that VET in the UK does not stimulate the creation of small companies enough (European Commission, 2011).

Given the benefits of entrepreneurship ${ }^{1}$ and the UK's position as one of the most entrepreneurial economies in the world, the study of why and how individuals who excel in vocational professions discover, evaluate, and exploit entrepreneurial opportunities is of practical and academic interest.

Earlier research (Mayhew et al., 2013) found that WorldSkills training helped competitors develop the necessary confidence, self-esteem and people skills to become entrepreneurial. The WSC is the largest vocational education and skills excellence event in the world. The competitors are selected from skills competitions in WorldSkills member countries. WorldSkills takes place every two years with competitors aged between 18 and 22. The UK fields competitors in around 40 different skill areas (James and Holmes, 2012), and the UK has competed in the competition since 1953 (Wilde and James Relly, 2015, p. 86).

Building on Mayhew et al.'s (2013) findings, in the present study we focus specifically on the entrepreneurial experience of young people who represented the UK at the WorldSkills Competition (WSC). ${ }^{2}$ Entrepreneurs have been compared to Olympic athletes who break new barriers (Kuratko, 2007), and so have the WorldSkills competitors who are the participants. We interviewed a sample of 40 WorldSkills competitors to learn about their entrepreneurial experience and motivations and how their training for and participation in WorldSkills might have contributed to these. Specifically, we aimed to answer the following research questions: How do WorldSkills competitors' psychological capital, social capital, and human capital facilitate the discovery, evaluation, and exploitation of opportunities to create future goods and services? How is the development of these three forms of capital linked with competitors' WorldSkills experience?

This article starts by introducing the conceptual framework of the study. It is followed by a description of the methodological approach which includes an overview of the study participants, the instruments used for data collection, the data analysis process, and the limitations of the research design. Following the methodology section, the findings of the study are presented.

There is ample literature on the pivotal contributions of entrepreneurship to economic growth through driving innovation and change (Landes, Mokyr, \& Baumol, 2012; Schumpeter, 1983), the equilibration of supply and demand (Kirzner, 1997), the conversion of new knowledge into products and services (Shane \& Venkataraman, 2000), and the development of human and intellectual capital (Zahra \& Dess, 2001).

2 The study is part of the Developing and understanding Vocational Excellence (DuVE) suite of research projects that is funded by Find a Future (formerly the National Apprenticeship Service), an organisation which brings together skills and careers initiatives from across the UK. 


\section{Conceptual Framework}

A variety of individual and contextual factors influence the development of entrepreneurship. This study identifies three individual-level factors - social capital, psychological capital, human capital - that may be associated with how WorldSkills competitors pursue (or not) entrepreneurial opportunities. The conceptual framework (Figure 1) sets out the main concepts that we examine in this study and the presumed relationships between them. We placed World Skills and entrepreneurship in the centre as these form the context of the study from which the subjects were selected.

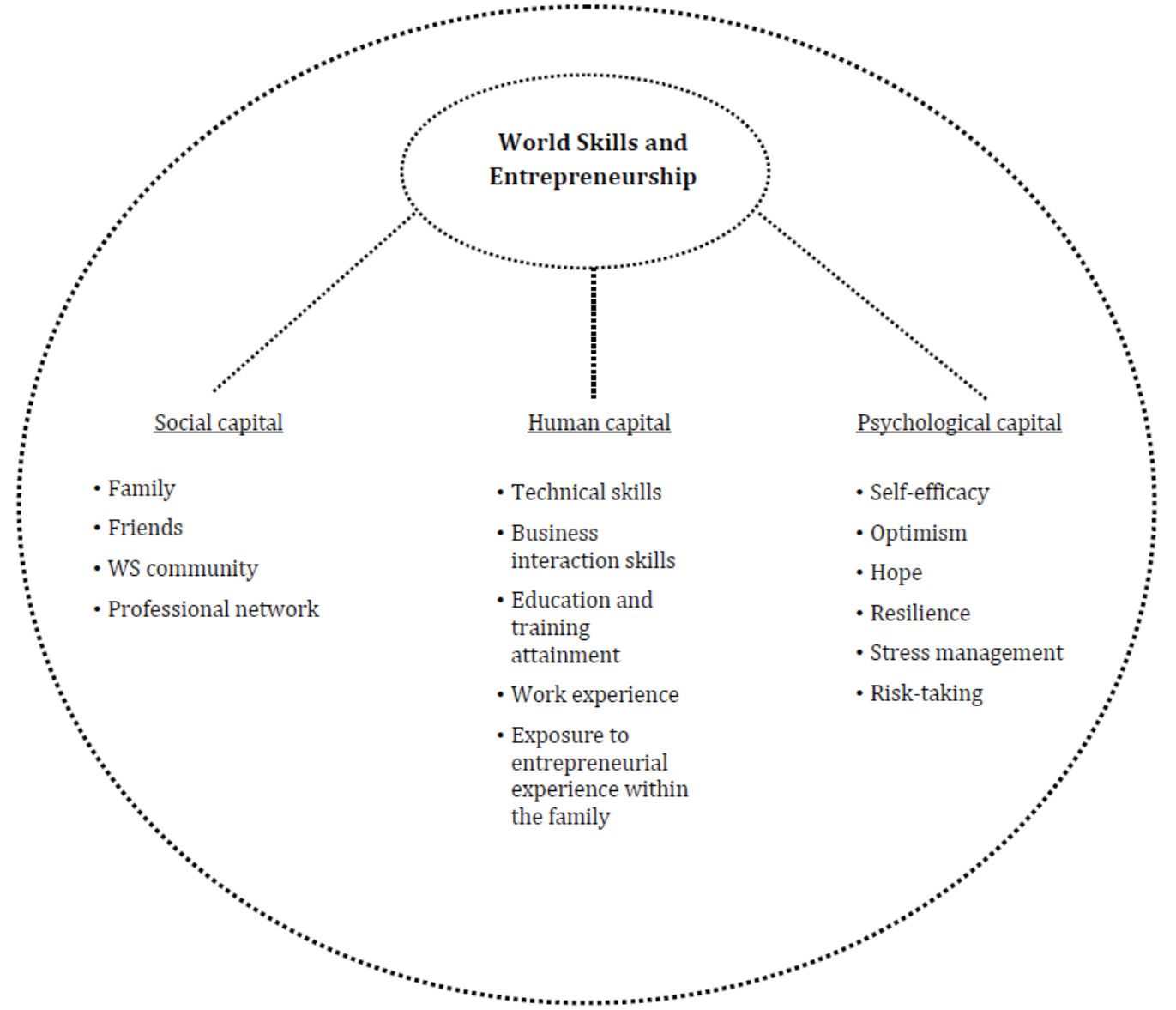

Figure 1. The conceptual framework

We define entrepreneurship as the process of the discovery, evaluation, and exploitation of opportunities to create future goods and services (Shane and Venkataraman, 2000, p. 218). The domains that this study examines focus on:

- entrepreneurship (firm creation/self-employment);

- intrapreneurship (entrepreneurship within existing organisations);

- and latent entrepreneurship.

Creating firms is the generally understood action and definition of an entrepreneur (Financial Times Lexicon, 2013a; Gartner, 1988, 1993). Given our sample of selfemployed and employed young people we have labelled the self-employed 
individuals as entrepreneurs. Intrapreneurs are individuals involved in the discovery of ideas or opportunities to create value, including activities that lead to the establishment of a new and self-financing organisation within an existing firm (Financial Times Lexicon, 2013b) and are part of the employed group in our sample. We labelled those individuals who declare preference for self-employment over employment, although they were still employed at the time of the interview (and were not exhibiting any intrapreneurship traits) as latent entrepreneurs; they are potential entrepreneurs. Finally, when referring to entrepreneurial individuals in this report, we include all the three categories - self-employed competitors, intrapreneurs and latent entrepreneurs.

In the study's conceptual framework, entrepreneurship is connected to three individual-level factors:

- Social capital: the key premise of social capital theory is that networks of relationships represent different types of actual and/or potential resources. Social capital is the advantage created by an individual's 'location in a structure of relationships' (Burt, 2005, p. 4);

- Human capital: For the purposes of this study, entrepreneurial human capital is the knowledge and skills that an individual has acquired through formal education and training (E\&T), work experience, non-formal/informal learning experiences that developed technical skills and business interaction skills, and any family history of entrepreneurship. These measures of human capital are similar to those used in the research literature (e.g. Bates, 1990; Davidsson and Honig, 2003; Mosey and Wright, 2007); and

- Psychological capital: In defining and operationalising psychological capital (PsyCap), we mainly rely on Luthans et al. (2007). PsyCap is defined as an individual's positive psychological state characterised by self-efficacy, optimism, hope, and resiliency;3

We have also collected data on competitors' self-reported ability to manage stress and their propensity to take risks. According to the literature, those who manage stress well and consider themselves to be risk-takers seem to be more entrepreneurial, with higher psychological capital than those who are risk-averse and easily stressed (Baron, et al., 2013; Kuratko, 2007).

3 Luthans et al. (2007) define self-efficacy as having the confidence to 'take on and put in the necessary effort to succeed at challenging tasks'(p. 3). In this study we use the terms self-efficacy and confidence interchangeably. Optimism is defined as 'making a positive attribution about succeeding now and in the future' (Luthans et al., 2007, p. 3). Hope is a more complex concept and consists of the willpower of 'persevering toward goals,' understanding of pathways that may lead to these goals, and the ability of 'redirecting paths to goals in order to succeed' (Luthans et al., 2007, p. 3). Luthans et al. (2007) identify hope with willpower. In interviews with competitors, we mostly used the word willpower (rather than hope) because of the perceived similarity in the meanings of optimism and hope. Finally, resiliency is 'the positive psychological capacity to rebound, to 'bounce back' from adversity, uncertainty, conflict, failure or even positive change, progress and increased responsibility' (Luthans 2002, p. 702). 


\section{Methodological Approach}

We collected qualitative and quantitative data and employed a combination of thematic and statistical techniques for the data analysis. In-depth semi-structured individual interviews was chosen as the most appropriate approach for exploring competitors' own understandings and interpretations of their experiences that helped (or did not help) the development of an entrepreneurial mindset.

\subsection{Participants}

To identify study participants, we used a combination of convenience sampling, snowballing, and purposive sampling. Participant recruitment started by contacting the WorldSkills competitors from the UK through Find a Future, the organisation responsible for Team UK. The exact number or year-group of the competitors on the mailing list remained unknown to the research group. In addition, we utilised a database of competitors created for an earlier DuVE project and telephoned those competitors to seek their participation. In total, 40 competitors agreed to participate in the study and interviews took place in person or by telephone at a time and location most convenient to respondents between March 2014 and December 2014. The sample of 40 participants included 30 entrepreneurial individuals: 13 entrepreneurs (nine had been self-employed prior to their participation in WorldSkills); four intrapreneurs; and 13 latent entrepreneurs. Ten competitors interviewed were not interested in entrepreneurship. The study participants covered all of the six WorldSkills sectors: Construction and Building Technology, Transportation and Logistics, Manufacturing and Engineering Technology, Information and Communication Technology, Social and Personal Services, Creative Arts and Fashion (Appendix 1).

The majority of the study participants (29) lived in England. Of the others, eight competitors lived in Northern Ireland, one in Wales and one in Scotland. One competitor lived abroad.

Eight participants were female and 32 were male, with an age range from 21 to 39 years old. The average age of participants who identified themselves as entrepreneurial was 25. This group included entrepreneurs, latent entrepreneurs, and intrapreneurs. The average age of participants who did not identify themselves as entrepreneurial was 24 .

The participants represented different WSC year groups 4 and all medal categories. Of the 40 competitors interviewed, two competed in 1997, one in 1999, one in 2001, three in 2007, six in 2009, 13 in 2011, and 14 in 2014. Two respondents were gold medallists, three were silver medallists, eight were bronze medallists, and 19 were awarded medallions of excellence. Eight participants did not win a medal or a medallion.

The average duration of self-employment was 63 months across the sample of entrepreneurs, with a median of 36 months. Eight of the 13 entrepreneurs had been in their businesses for three years or less at the time of the interview.

We obtained informed consent from each participant prior to audio-recording their interviews. To ensure confidentiality, none of the participants are named, and we have taken all necessary precautions to avoid identification of individuals.

4 Twenty-three interviewees were involved with WorldSkills in some capacity at the time of the interview. Of these, 15 were entrepreneurial and eight were not interested in entrepreneurship. 
When referring to study participants, we indicate the year of their participation in the WSC and differentiate between entrepreneurs (E), intrapreneurs (I), latent entrepreneurs (L), and those not interested in entrepreneurship (N).

\subsection{Instruments}

This study used semi-structured interviews with open-ended questions as the main research instrument. The process of designing the instrument started with identifying factual, thematic, and theoretical categories stemming from the research questions. Empirical and theoretical literature on entrepreneurship, social capital, psychological capital, human capital, and entrepreneurial motivation, as well as the research team's substantive knowledge and research evidence on WorldSkills were used in the process of designing the protocol. We first developed the interview protocol for entrepreneurs, then created three variations of this protocol to be used with intrapreneurs, latent entrepreneurs, and those not interested in entrepreneurship.

The first version of the interview protocol was pilot tested with a competitor who participated in EuroSkills in 2008 in Rotterdam. The PsyCap questionnaire, developed by Luthansio et al. (2007) was used to measure the construct of psychological capital. The participants were asked to complete the questionnaire after answering the interview questions.

\subsection{Data analysis}

The qualitative (interview) and quantitative (PsyCap questionnaire) data were analysed using the various techniques explained below.

The qualitative data was analysed in several stages. The audio-recorded interviews were first transcribed. Using NVivo software, narratives were broken down into 74 nodes that represented factual, thematic, analytical, and formal categories. Factual categories refer to objective data, such as age, year of participation in WSC, gender, medal information, size of business, or date of becoming self-employed. Thematic categories refer to specific constructs discussed in the conceptual framework, such as influences of WorldSkills on developing social capital, psychological capital, human capital, and entrepreneurial motivation, relationships between geographical and sectoral contexts and entrepreneurship. Theoretical categories refer to the evidence related to specific theoretical constructs from the existing literature, for example, trust, optimism, resiliency, and entrepreneurial motivation. Finally, formal categories refer to the place and date of the interview, interview length, and mode of interview (face-to-face or telephone).

The first draft of nodes was generated using the interview protocol and its three variations. These nodes were revised and other nodes were added as we proceeded with the process of coding the interview data. At the final stage of the thematic analysis, we systematically grouped the nodes in relation to the thematic and theoretical categories pertaining to each sub-question.

The quantitative data included the PsyCap questionnaire results. In addition, SPSS software was used to generate some basic descriptive statistics on the qualitative data.

\subsection{Limitations}

This study has two limitations. First, it relied on self-reporting. Second, it gathered data from 40 non-randomly selected competitors, and the findings cannot 
necessarily be generalised to the population of WorldSkills UK competitors or to WorldSkills competitors in general. Thus, the findings should be interpreted as illustrative for understanding the relationship between WorldSkills experience and the development of entrepreneurship.

\section{$4 \quad$ Findings and discussion}

\subsection{Psychological capital and entrepreneurship}

Psychological capital is an individual's positive psychological state characterised by self-efficacy, optimism, hope, and resiliency (Luthans et al., 2007). In this study, self-efficacy is identified with confidence; hope is identified with willpower. We also gathered data on competitors' self-reported ability to manage stress and their propensity to take risks.

The PsyCap questionnaire analysis showed that the average PsyCap scores were highest for intrapreneurs (5.39) and entrepreneurs (5.38) (Figure 2). ${ }^{5}$

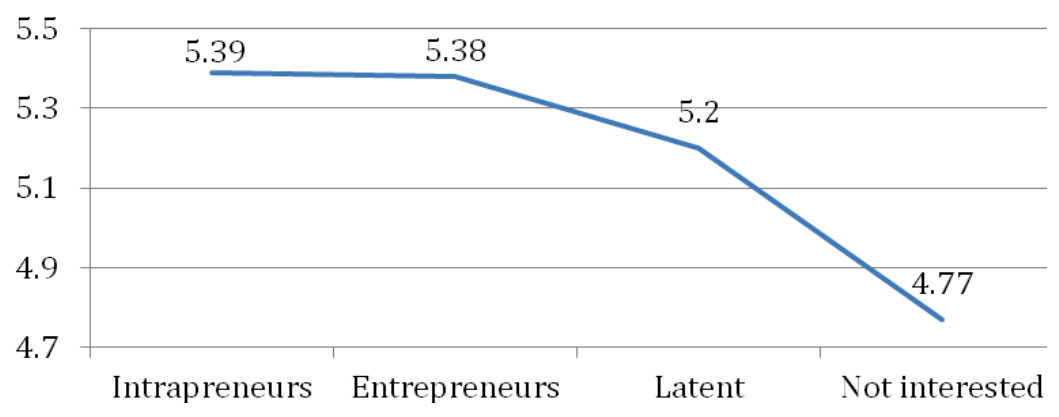

Figure 2. Psychological capital: average scores for different groups

We asked WorldSkills competitors to think of one experience that had the strongest influence on developing each of the components of psychological capital: selfefficacy, optimism, hope, and resiliency. The analysis of the responses showed that $95 \%$ of the participants recognised WorldSkills as the most important lifetime experience that had developed their self-efficacy (Figure 3). However, around onethird participants considered WorldSkills experience to be their most influential lifetime experience for developing optimism, resiliency, or hope. For the majority of WorldSkills competitors, the most important influences on the development of these three characteristics were related to their childhood/parents, workplace experience, school experience, health-related issues, or religious beliefs.

5 We conducted independent samples t-tests to check if the mean PsyCap scores were different for any of the four groups when compared to others and for the entrepreneurial group $(n=30)$ when compared to the non-entrepreneurial group $(n=10)$. None of the five t-tests showed statistically significant differences between groups. 


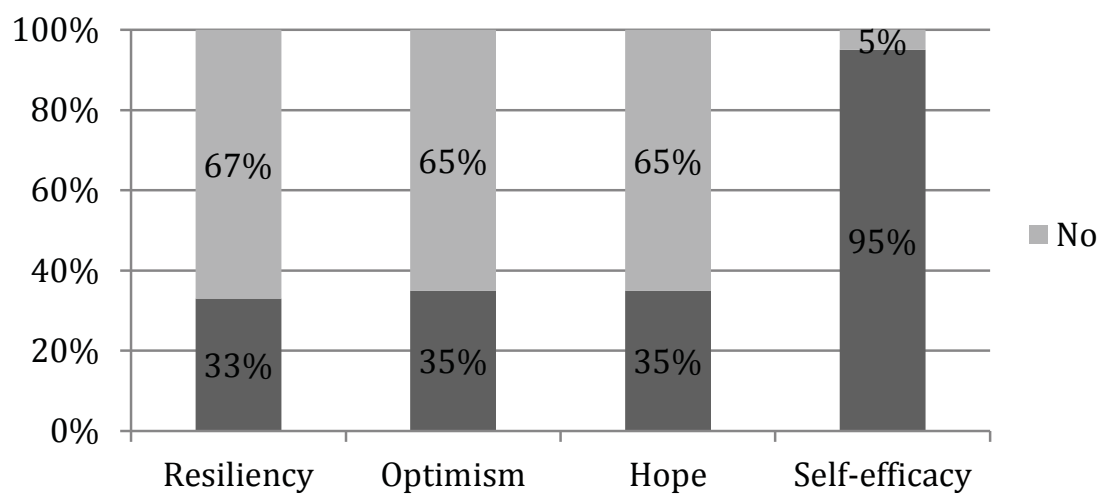

Figure 3. The proportions of participants who recognised WorldSkills as the most important influence for the development of these psychological characteristics $(n=40)$

\subsection{Social capital and entrepreneurship}

The topic of social capital and entrepreneurship has received considerable attention in the business literature. Social capital may be a catalyst, obstacle, or unrelated to entrepreneurship (Light and Dana, 2013). This study mainly focused on whether the networks developed through WorldSkills served as a catalyst for competitors' professional success, especially for entrepreneurs. An intrapreneur explained that there are:

very few occasions when you achieve something completely on your own. You rely on other people, whether it's your partner making you dinner when you get home, or whether it's a supplier who has to send something on time. The relationships you build up around your entrepreneurship, or your business, really matter (I1, 1999).

Participants identified five networks as the most important for their professional success: family networks, friendship networks, professional networks, customer networks, and WorldSkills community networks (which sometimes overlapped with friends and professional contacts).

WorldSkills competitors recognised professional networks as the most important for their professional success, followed by family networks (see Table 1). Nearly half of the respondents talked about the value of the WorldSkills networks for their professional success. While the professional and WorldSkills community networks were considered important by similar proportions of entrepreneurial and non-entrepreneurial individuals, these two groups differed in their reliance on friends and family. Nearly twice the proportion of entrepreneurial individuals recognised friends and family as relevant networks for their professional success compared with non-entrepreneurial individuals (Table 1). 
Table 1. Importance of different networks

\begin{tabular}{lll}
\hline $\begin{array}{l}\text { Type of } \\
\text { network }\end{array}$ & $\begin{array}{l}\text { Entrepreneurial } \\
\text { category }\end{array}$ & $\begin{array}{l}\% \text { (number of respondents } \\
\text { in the entrepreneurial or } \\
\text { non-entrepreneurial } \\
\text { groups respectively) } \\
\text { recognising the } \\
\text { importance of the network }\end{array}$ \\
\hline $\begin{array}{l}\text { Professional } \\
\text { networks }\end{array}$ & $\begin{array}{l}\text { Entrepreneurial } \\
\text { Non-entrepreneurial }\end{array}$ & $\begin{array}{l}80 \%(24) \\
80 \%(8)\end{array}$ \\
$\begin{array}{l}\text { Family } \\
\text { networks }\end{array}$ & Entrepreneurial & $67 \%(20)$ \\
$\begin{array}{l}\text { WorldSkills } \\
\text { community } \\
\text { networks }\end{array}$ & Entrepreneurial & $30 \%(3)$ \\
$\begin{array}{l}\text { Customer- } \\
\text { base }\end{array}$ & Non-entrepreneurial & $50 \%(14)$ \\
Friends & Non-entrepreneurial & $0 \%(0)$ \\
& Entrepreneurial & $20 \%(6)$ \\
& Non-entrepreneurial & $10 \%(1)$ \\
\hline
\end{tabular}

Social capital may be associated with a number of benefits for entrepreneurs. It may improve the chances of survival and growth of new businesses (Brüderl and Preisendörfer, 1998), allow access to potentially valuable information (Baron, 2013; Galindo, 2008; Hoang and Antoncic, 2003), give access to advice and encouragement (Baron, 2013; Hoang and Antoncic, 2003), provide emotional support to entrepreneurs (Birley, 1985), give increased access to financial resources (Baron, 2013; Birley, 1985; Galindo, 2008), and develop trust (Baron, 2013).

A majority of entrepreneurial individuals indicated that social networks contributed or were expected to contribute to their business development. Very often, these networks were related to work/college experiences or family networks. In a number of cases, networks were acquired through the competition experience. For example, an entrepreneur $(E 10,2011)$ explained that he had been working closely with two people from the WorldSkills squad. They had slightly different specialisations in the same skill sector and complemented one another. One of those colleagues was planning to move from Northern Ireland to England and work for E10's business. Another entrepreneur saw considerable benefits from keeping in touch with his training manager: 'My training manager has been fantastic. He's always tried to help me work wise, if anybody has needed any work done he's always recommended me, and that sort of thing' (E13, 2011). Yet another competitor thought his business benefitted from collaborations with other WorldSkills competitors:

When I do big projects in the UK or [abroad], I take over there a girl who I trained for WorldSkills. Two other girls who made the squad and one girl made the team. I trained them and mentored them. They now own shops that are businesses and studios. They are always up for something exciting. If I say 
"Do you want to go to Ireland for a week and help me?" "Yes, yes we will." $(\mathrm{E} 5,2009)$

Latent entrepreneurs hoped to be able to employ WorldSkills ex-competitors when they were in the position of being able to offer jobs: 'definitely they would be your first choice, $100 \%$. That would be the first people that you would want to work for you' (L10, 2007).

Networks allowed access to potentially valuable information. One of the latent entrepreneurs said he would definitely turn to his training manager in providing support in terms of relevant information at the time of starting his own business. 'He is sort of my guardian angel, really,' said the competitor (L12, 2009). In addition to training managers, fellow competitors were also a supportive source of advice and guidance. One of the entrepreneurs recollected the responses of people outside his close network after he had described an idea for a new product. He said people reacted with 'That's not realistic' or 'You're stupid', whereas his close friend and a fellow WorldSkills competitor always encouraged him with words like 'Genius, I love it. You're the man' (E14, 2013). There was another case when the networks acquired through WorldSkills encouraged the pursuit of entrepreneurial ideas by showing how self-employment can work: 'It was a case of meeting a few of the lads and lasses [through the WorldSkills] that were already self-employed, and I thought, Christ, they're only twenty-five and they've got their own business, and supporting themselves from it. I thought that was brilliant' (E12, 2009).

One of the main assumptions behind the benefits of social capital is that the goodwill, trust, or sympathy of other people is a valuable resource (Adler and Kwon, 2002, p. 18). In business networks, trust is crucial and may be defined as 'a confident and warranted belief that the other party will honour their obligations' (Casson and Giusta, 2007, pp. 228-229). The issue of trust emerged as a topic of discussion with 14 WorldSkills competitors, all of them entrepreneurial: 'I know people that I can trust and rely on' $(E 13,2011)$ or 'these are people that I would trust, which is very important, to have the same core ethic as me and the same motivation as me, very similar characters to me' (L8, 1997). Family and friends constituted the most trustworthy networks for entrepreneurial competitors.

Although the literature notes that keeping and developing social networks can have costs (Adler and Kwon, 2002), most of the interviewees did not see the investment in building social networks as a cost. For example, when asked what kinds of costs were associated with developing professional networks, one of the entrepreneurs responded: 'I see it as being able to give. It is not a cost at all. That's a horrible way to think about it. I don't want to say there are costs involved at all' (E5, 2009). In contrast, those WorldSkills competitors who did not invest as much as others in keeping active and/or expanding their networks, especially the WorldSkills network, used the argument of costs to explain their lack of investment, often referring specifically to the costs related to geographical separation:

If someone called me and said, "Do you fancy a quick drink tomorrow night in Edinburgh?" I will be like "No, I don't, not really." I can't travel that far, that was the problem with WorldSkills, everyone was from all over the UK but it was always in London where we met (E2, 2001).

Whether individuals build networks with people who have similar or different opinions and practices to their own may be related with the propensity to form new ideas, generate growth, and create innovation. Building networks with people who have similar opinions and practices to one's own is known as closure, and building 
networks with people who have different opinions and practices from one's own is referred to as brokerage (Burt, 2005). Closure helps to strengthen connections within groups, enhancing trust and alignment, and resulting in improved efficiency; brokerage allows the building of connections across groups and is associated with growth, innovation and higher likelihood of detecting and developing good ideas. We asked interviewees whether their networks connected them to professional practices that were different from their own (brokerage) or similar to their own (closure). A chi-square test showed that there was a significant difference in the type of networks that entrepreneurial and non-entrepreneurial individuals had built. Namely, the most important networks of all ten non-entrepreneurial individuals included people with similar professional backgrounds. Amongst the entrepreneurial group, the majority had brokerage networks (17 individuals).

A third mechanism - linking - is also mentioned in the literature. While brokerage and closure are horizontal metaphors, linking is a vertical metaphor. Linking social capital implies connecting with groups or individuals who are at a different level of social hierarchy, building relationships with people in positions of power (Woolcock, 2002). A few of the competitors talked about the role of the WorldSkills community in helping them to link with individuals in positions of power, for example, people from Whitehall, the Royal Family, or business leaders. Whilst there was no evidence that connections with government officials or royalty resulted in professional benefits, exposure to business leaders seemed to be most useful for entrepreneurial individuals:

[Business leaders] would be more useful than other networks, without a doubt, because they're the ones that are actually in the [industry] now, they're the ones that are kind of live now, whereas the princes, and all these other highprofile people you don't speak to them again. The only real networks that I got from there where I gained things were [the companies] which do all the products - they basically said to me, if you ever need any products in the future, let us know, and we'll supply you products at, like, cheap prices (L5, 2011).

Finally, this study aligns with Adler and Kwon's (2002) work that it is through ability, motivation, and opportunity that social capital is activated. A few participants acknowledged that WorldSkills put competitors in environments where opportunities to network were high, thus helping to develop the confidence and communication skills that contributed to expanding individuals' social networks:

[WorldSkills] gives you the right tools to go and network, you can ask questions and you feel confident asking the questions. It puts you where high profile [professionals] would be, like designers to go and work with them, you would never get that anywhere. You go and you use what you can to make the most of that opportunity so it's not wasted and you keep in touch with those people just through meeting them, all the judges and designers. Not always but they get in touch with you back. (E9, 2011)

\subsection{Human capital and entrepreneurship}

For the purposes of this study, human capital comprises five elements: education and training (E\&T) attainment, technical skills, business interaction skills, work experience, and exposure to entrepreneurship within the family. We discussed family networks in the previous section on social capital. In this section we focus specifically on the entrepreneurial knowledge that became available to some competitors through their family experiences of self-employment. WorldSkills 
emerged as the major contributor to two of these five elements - technical skills development and business interaction skills development.

\section{Technical skills}

WorldSkills training significantly helps the development of competitors' excellence in their respective vocational skill areas (Mayhew et al., 2013). Eighty-eight per cent of the interviewees in this study acknowledged the influence of WorldSkills on the development of their technical skills.

We looked at the association between winning medals, as one indicator of possessing the highest level of technical skills, and entrepreneurship. We discovered that amongst those who did not win a medal or won a medallion of excellence, there were almost equal proportions of entrepreneurial and nonentrepreneurial individuals. However, those who won gold and silver medals (13\% of all respondents) were all entrepreneurial. A bronze winner explained how the technical skills he developed through WorldSkills helped him in his business:

because all the training was by hand, because that's what the competition is, it's the old-fashioned way. That was really useful because that's probably what taught me all the hand skills... the very bespoke stuff, and that's what people pay for, if it's done by hand, because anybody can push something through a machine. Or very unusual things, sometimes there isn't a machine to do the job. (E10, 2011)

Many competitors argued that WorldSkills turned them into perfectionists; they consistently worked to achieve the highest quality in order to make the products or services they offered exceptionally attractive to their customers:

It's in terms of trying to get people to go 'wow'. Because, ultimately, when you've got your own business, you need to delight your customers, and that's what keeps them coming back. If I had to connect it to the competition stuff, I'd say that doing competitions forces you to think, what's going to make people go 'wow'. I'd never really thought of it quite in that way before. That's what competitions do. They force you to think, what's going to make somebody go 'that's fantastic' (E5, 2009).

One important aspect of technical skills development that helped self-employed competitors was the development of the knowledge and skills of working efficiently, focusing on those parts of the work that matter the most, while saving time and materials:

Making it as efficiently as possible, and making sure that the quality matters where it needs to matter, and where it's not seen, doesn't matter, where you can cut corners, if that makes sense. That's where you make the money by...it sounds bad, by cutting corners, because... so you learn a lot about that [through WorldSkills] (E14, 2013).

\section{Business interaction skills}

The way WorldSkills competitors approached the people around them and their own work seemed to be crucial for their successful self-employment. We refer to these skills as business interaction skills or people skills:

Obviously, being in WorldSkills, you learn a lot of people skills. You get a lot of interviews. You meet a lot of people. Your people skills grow a lot. I mean, I can happily talk to a customer now; before that, I was a bit shy $(\mathrm{E} 14,2013)$. One aspect of communication skills that some entrepreneurial competitors found particularly useful was discussing difficult topics with others. They argued that the 
WorldSkills experience and, in particular, negotiations with employers regarding training time, helped them improve skills that they then used with difficult customers. This aspect of business interaction skills development overlaps with one of the aspects of psychological capital - confidence - discussed earlier.

Some interviewees talked about the approaches to work and people used in the process of competitor training. This included rejecting routine approaches and adopting unconventional ways of thinking, being organised, taking responsibility for paperwork, seeking excellence in everything, and seeking to work with people who are perfectionists. The following two quotes demonstrate how two entrepreneurial competitors reflected on WorldSkills and its positive role in changing their approaches to work and people:

What competitions do is they force you to think in a different way to how you do on a day-to-day basis. In your day-to-day work it's possible to end up thinking in quite a routine way. What a competition does is it says, you need to get to a different result, therefore, thinking in the same way won't work. I'm just basing this on experience; what competitions do, they force you, with a bit of adrenalin, to think about a different challenge, and it is quite invigorating. (I1, 1999)

The competition seems to have had varying influences on participants' business interaction skills development; some benefited from it more than others. Those who talked in great detail about the relevance of people skills seem to have also been more successful in using the WorldSkills name for promoting their business. These interviewees considered their WorldSkills experience as a good tool for publicity that would result in more clients.

'It's a big stepping-stone,' said L5 (2011), 'you've only got to type my name in Google and see that I was crowned. So I could use that as advertising.' Another competitor explained that WorldSkills experience 'sounds impressive when you're telling someone about it, it's definitely helped me gain a few clients, and for them to get confidence in me because they've seen what I've done' (E4, 2011). A recent competitor said he used the WorldSkills name on an advert in his village because everyone knew him and might not have had a great deal of trust in his abilities because of his young age. The advert worked effectively, the competitor said, as the international success story made his potential clients realise he could do the job (E10, 2011).

Another competitor thought his WorldSkills medal presented an excellent selling point for his future business:

'When you are pitching yourself, it gives them a bit of faith in that you have achieved something on a world level, and it proves to them your capabilities of being able to do their work to the highest standard' (L7, 2011).

Again, this benefit largely depended on the business interaction skills that WorldSkills competitors developed through their WorldSkills experience.

\section{Education and training attainment}

Three aspects of education and training (E\&T) attainment are relevant for this study: competitors' experience of entrepreneurship education, the qualification attained by participants, and their plans for pursuing E\&T in the future.

Competitors reported little formal experience with entrepreneurship education. Very few had taken any courses in business studies, accounting, finance, management, or a related subject, either as part of their qualifications, continued professional development, or independently of a work or study programme. Only 
one respondent, who participated in the competition in 2001, mentioned a specific training programme provided during the WorldSkills training that was focused on business skills development. This training consisted of workshops giving scenarios of how to cope with running a business. There were also role-play exercises based on different business situations:

There is no way it couldn't have helped. There was no way it has no effect when you were given lots and lots of scenarios and lots and lots of case work and lots of competition and lots of interviews, and lots of paperwork; there is no way that that didn't give me something which I have taken out of it in today's life. (E2, 2001)

We looked at the differences in the E\&T qualifications attained by entrepreneurial and non-entrepreneurial individuals. A t-test demonstrated that the average level of E\&T attainment, as expressed by Qualifications and Credit Framework (QCF), was Level 4 for 30 entrepreneurial competitors and Level 5 for ten non-entrepreneurial competitors. Additionally, WorldSkills competitors were asked if they felt they would need to pursue any E\&T in the future, by attending a training course or acquiring a formal qualification. We classified competitors' responses into three groups: none, some, and extensive. The differences between the entrepreneurial and non-entrepreneurial groups emerged through chi-square analysis. Amongst ten non-entrepreneurial individuals, only one did not plan to pursue any E\&T in the future. Amongst 30 entrepreneurial individuals, 14 did not plan to pursue any E\&T. Both groups, however, intended to undertake or upgrade industry certifications as required by their respective industries. These findings may point to the possibility that higher levels of E\&T attainment are not necessarily associated with a higher likelihood of entrepreneurial pursuits.

\section{Work experience}

For the purposes of this study, work experience is defined as any experience that an individual acquires when working in a specific occupation. Across the sample as a whole, entrepreneurial individuals had more work experience (on average, 50 months) than non-entrepreneurial individuals (on average, 38 months). This difference should be viewed in the light of another statistic - participants' age; there was no significant difference in the mean age of entrepreneurial (25) and nonentrepreneurial (24) individuals included in our sample.

All latent entrepreneurs remained in employment as they did not feel ready to start their own business due either to a lack of initial capital and/or their perceived lack of essential business management skills. When talking about the future, latent entrepreneurs and intrapreneurs mentioned the word 'learning' more often than selfemployed individuals. What they often meant was learning in the workplace that helped them acquire those basic skills of management that would allow them to be self-employed: 'I think workplace learning suits me more. I'm much more practical, I need to do it to learn it' $(\mathrm{L} 1,2013)$. One of the latent entrepreneurs explained how he changed jobs from a large non-profit to a large for-profit company in order to gain more diverse experience of how a profit-making firm works:

I had got that kind of corporate experience, the ability to work in a team, how to manage projects, that kind of stuff. It [was] not a commercial, money-making business, so the next thing for me was to learn, okay, so how do you then make money, you know, or how do you then do something in an environment that's built to make money, so it's a very different way of looking at it. So, eventually, at 
some point I can put all these pieces together to then, eventually, go off by myself. (L4, 2009)

\section{Exposure to entrepreneurial experience within the family}

We asked WorldSkills competitors about entrepreneurial experience within their families and classified the respondents into those who had a self-employed family member and those who did not. Amongst the non-entrepreneurial group of WorldSkills competitors, one-fifth had entrepreneurial experience in their family, while four-fifths of entrepreneurial competitors had a family member who owned a business or was self-employed.

Having an entrepreneurial family member was associated with multiple benefits for entrepreneurs, in terms of psychological capital (resiliency), human capital (knowledge of finance and accounting practices), and social capital (networks).

Most of the family experiences of entrepreneurship described were success stories: '[My uncle] is self-made. He had his own house built up in the mountains in [Europe]. He's living the dream!' (L8, 1997). However, there were also cases of unsuccessful entrepreneurial experiences of family members which seemed to have affected the individuals interviewed and somewhat delayed their decision to become self-employed. A latent entrepreneur described a traumatic case of his step-dad going bankrupt and how this had developed his resiliency, although made him feel more cautious about opening his own firm (L4, 2009). Another latent entrepreneur talked about the failure of their family business and how the family struggled for subsequent years. Here again, the entrepreneur felt that the experience had improved his resiliency and made him more 'determined to get everyone back on their feet' (L12, 2009).

Family history of entrepreneurship reportedly made most of the entrepreneurial individuals more motivated to be entrepreneurs themselves. As one latent entrepreneur noted: 'my dad's done very well for himself, I'd be quite pleased if I'd done as well as my dad had' (L9, 2009). Another latent entrepreneur was also inspired by his father:

He's been one of my main inspirations through the whole thing. I don't think I would have got here if I didn't have such a massive support network at home but he's very sort of if you want it go and get it. Life won't hand it to you on a silver platter. If you want something you need to go and get it and work hard to get it. (L6, 2013)

Having a self-employed individual or a firm owner at home represented a considerable benefit in terms of getting advice on matters related to running a business, especially on the finance and accounting side. The majority of the entrepreneurs interviewed with an entrepreneurial family member received some help and advice on running a business from them.

Family tradition influenced WorldSkills competitors not only through the entrepreneurial experiences that they witnessed on a day-to-day basis but also through the networks that they acquired via family business connections:

Probably part of it will be drawn on the experience of my father as well. Obviously he has been running the business now for about 30 years, so he has built up a lot of contacts in terms of builders and contacts related to public sector work as well. So probably on that, and I suppose as well just family and friends on a more personal level, the motivation that they give you to try and move forward and that sort of support $(\mathrm{L} 7,2011)$. 
The interviews with non-entrepreneurial competitors demonstrated that many of them did not have any self-employed individuals at home, at work, or among friends: 'I don't know anyone who's self-employed. They're employed with companies' (N9, 2011).

\section{Conclusion}

Through our research we sought to examine how WorldSkills competitors recognized and took advantage of opportunities to create future goods and services. Specifically, we were interested in how, if at all, WorldSkills experiences facilitated the process of the discovery, evaluation, and exploitation of entrepreneurial opportunities. A variety of individual factors influence the development of entrepreneurship. In this study we focused on three non-discrete individual-level factors - social capital, psychological capital, and human capital. Identifying the influence of social phenomena is considered to be an extremely complex process in social scientific research since counterfactuals can rarely be known. Linking entrepreneurial experiences with WorldSkills was not a simple task; the majority of study participants saw some connections between the two experiences, but not all of these connections were easy to pin down.

We established links between WorldSkills competitors' social capital, psychological capital, human capital and how the competition experience contributed to the enhancement of different aspects of these three types of capital. Our research findings pointed towards the conclusion that training for and participation in WorldSkills enabled entrepreneurship by developing competitors' social networks, psychological characteristics, and technical and business interaction skills. However, the majority of entrepreneurial competitors had been entrepreneurial before they started training for WorldSkills; they were already selfemployed, intrapreneurs or latent entrepreneurs. In other words, strong entrepreneurial motivation often preceded participants' engagement with competitions. 


\section{References}

Adler, P.S., \& Kwon, S.-W. (2002). Social Capital: Prospects for a New Concept. Academy of Management Review, 27(1), 17-40.

Baron, R.A. (2013). Enhancing entrepreneurial excellence: tools for making the possible real. Cheltenham: Edward Elgar.

Baron, R.A., Franklin, R.J., \& Hmieleski, K.M. (2013). Why Entrepreneurs Often Experience Low, Not High, Levels of Stress. The Joint Effects of Selection and Psychological Capital. Journal of Management 42(3). doi: 10.1177/ 0149206313495411.

Bates, T. (1990). Entrepreneur Human Capital Inputs and Small Business Longevity. The Review of Economics and Statistics, 72(4), 551-559.

Birley, S. (1985). The role of networks in the entrepreneurial process. Journal of Business Venturing, 1(1), 107-117. doi: 10.1016/0883-9026(85)90010-2.

Brüderl, J., \& Preisendörfer, P. (1998). Network Support and the Success of Newly Founded Business. Small Business Economics, 10(3), 213-225. doi: 10.1023/ A:1007997102930.

Burt, R.S. (2005). Brokerage and closure: an introduction to social capital. Oxford, New York: Oxford University Press.

Casson, M., \& Giusta, M.D. (2007). Entrepreneurship and Social Capital Analysing the Impact of Social Networks on Entrepreneurial Activity from a Rational Action Perspective. International Small Business Journal, 25(3), 220-244. doi: 10.1177/0266242607076524.

Davidsson, P., \& Honig, B. (2003). The role of social and human capital among nascent entrepreneurs. Journal of Business Venturing, 18(3), 301-331. doi: 10.1016/S0883-9026(02)00097-6.

European Commission. (2011). Attitudes towards vocational education and training: Special Eurobarometer 369. Retrieved from http://ec.europa.eu/public_opinion/archives/ebs/ebs_369_en.pdf.

Financial Times Lexicon (2013a). Definition of entrepreneurship. Retrieved 26 November 2014, from http://lexicon.ft.com/Term?term=entrepreneurship.

Financial Times Lexicon. (2013b). Definition of intrapreneurship. Retrieved 26 November 2014 from http://lexicon.ft.com/Term?term=intrapreneurship.

Galindo, M.-A. (2008). Entrepreneurship and Business: A Regional Perspective. Berlin: Springer.

Gartner, W.B. (1988). 'Who is an Entrepreneur?' Is the Wrong Question. American Journal of Small Business, 12(4), 11-32.

Gartner, W.B. (1993). Words lead to deeds: Towards an organizational emergence vocabulary. Journal of Business Venturing, 8(3), 231-239. doi: 10.1016/ 0883-9026(93)90029-5.

GEDI (2014). Global Entrepreneurship and Development Institute: UK profile. Retrieved 21 November 2014, from http://thegedi.org/countries/united kingdom.

Hoang, H., \& Antoncic, B. (2003). Network-based research in entrepreneurship - A critical review. Journal of Business Venturing, 18(2), 165-187. doi: 10.1016/ S0883-9026(02)00081-2.

James, S., \& Holmes, C. (2012). Developing vocational excellence: learning environments within work environments (SKOPE Working Paper No. 112). Oxford: University of Oxford. 
Kirzner, I.M. (1997). Entrepreneurial Discovery and the Competitive Market Process: An Austrian Approach. Journal of Economic Literature, 35(1), 60-85.

Kuratko, D.F. (2007). Entrepreneurial leadership in the 21st century: Guest editor's perspective. Journal of Leadership \& Organizational Studies, 13(4), 1-11. doi: 10.1177/10717919070130040201.

Landes, D.S., Mokyr, J., \& Baumol, W.J. (Eds.). (2012). The Invention of Enterprise: Entrepreneurship from Ancient Mesopotamia to Modern Times. Princeton: Princeton University Press.

Light, I., \& Dana, L.-P. (2013). Boundaries of Social Capital in Entrepreneurship. Entrepreneurship Theory and Practice, 37(3), 603-624. doi: /10.1111/etap.12016.

Luthans, F. (2002). The need for and meaning of positive organizational behavior. Journal of Organizational Behavior, 23(6), 695-706. doi: 10.1002/job.165.

Luthans, F., Youssef, C.M., \& Avolio, B.J. (2007). Psychological capital: developing the human competitive edge. Oxford, New York: Oxford University Press.

Mayhew, K., James, S., Chankseliani, M., \& Laczik, A. (2013). Benefits of Developing Vocational Excellence. A Report to the National Apprenticeship Service of Project 3 of the DUVE suite of projects. Oxford, UK: University of Oxford. Retrieved from http://vocationalexcellence.education.ox.ac.uk/ourresearch/project-3/.

Mosey, S., \& Wright, M. (2007). From Human Capital to Social Capital: A Longitudinal Study of Technology-Based Academic Entrepreneurs. Entrepreneurship. Theory and Practice, 31(6), 909-935. doi: 10.1111/j.15406520.2007.00203.x.

ONS (2013). Employment status of people in employment, April-June 2012, UK. Retrieved 28 November 2013, from http://www.ons.gov.uk/ ons/publications/re-reference-tables.html?edition=tcm\%3A77-295472.

Schumpeter, J.A. (1983). The theory of economic development: an inquiry into profits, capital, credit, interest, and the business cycle. New Brunswick, N.J.; London, UK: Transaction Publishers.

Shane, S., \& Venkataraman, S. (2000). The Promise of Entrepreneurship as a Field of Research. Academy of Management Review, 25(1), 217-226. doi: 10.5465/ AMR.2000.2791611.

startups.co.uk. (2011). $80 \%$ of British teenagers want to become entrepreneurs. Retrieved 8 October 2014, from http://startups.co.uk/80-of-british-teenagerswant-to-become-entrepreneurs/.

Wilde, S., \& James Relly, S. (2015). WorldSkills UK Training Managers: Midas Touch or Fool's Gold? International Journal for Research in Vocational Education and Training, 2(2). doi: 10.13152/IJRVET.2.2.1.

Woolcock, M. (2002). Social capital in theory and Practice: where do we stand? In J. Isham, T. Kelly, \& S. Ramaswamy (Eds.), Social Capital and Economic Development: Well-being in Developing Countries (pp. 18-39). Cheltenham, UK: Edward Elgar Publishing.

Zahra, S., \& Dess, G.G. (2001). Entrepreneurship As a Field of Research: Encouraging Dialogue and Debate. Academy of Management Review, 26(1), 8-10. doi: 10.5465/AMR.2001.4011916. 


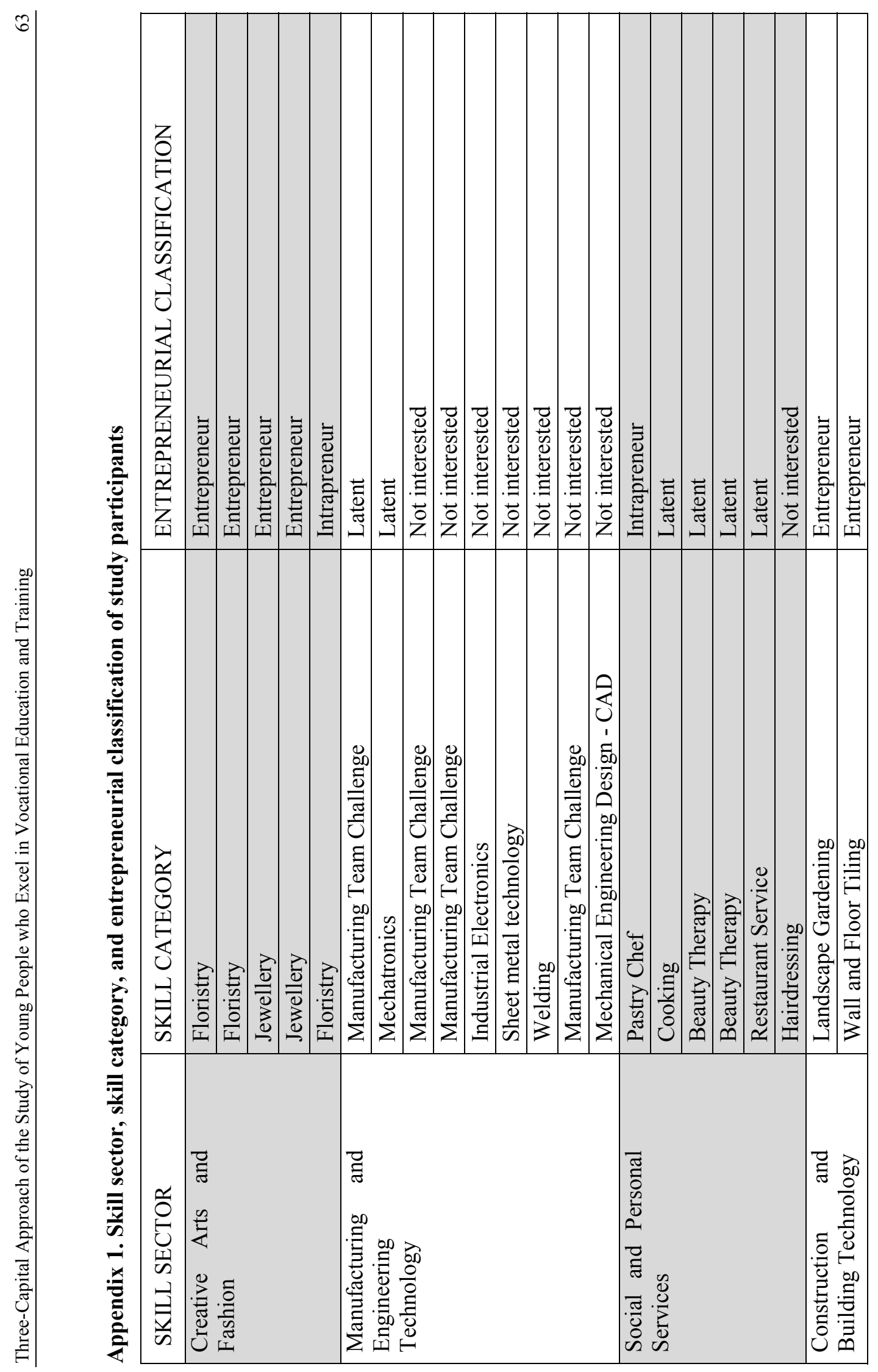

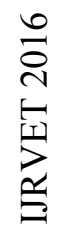




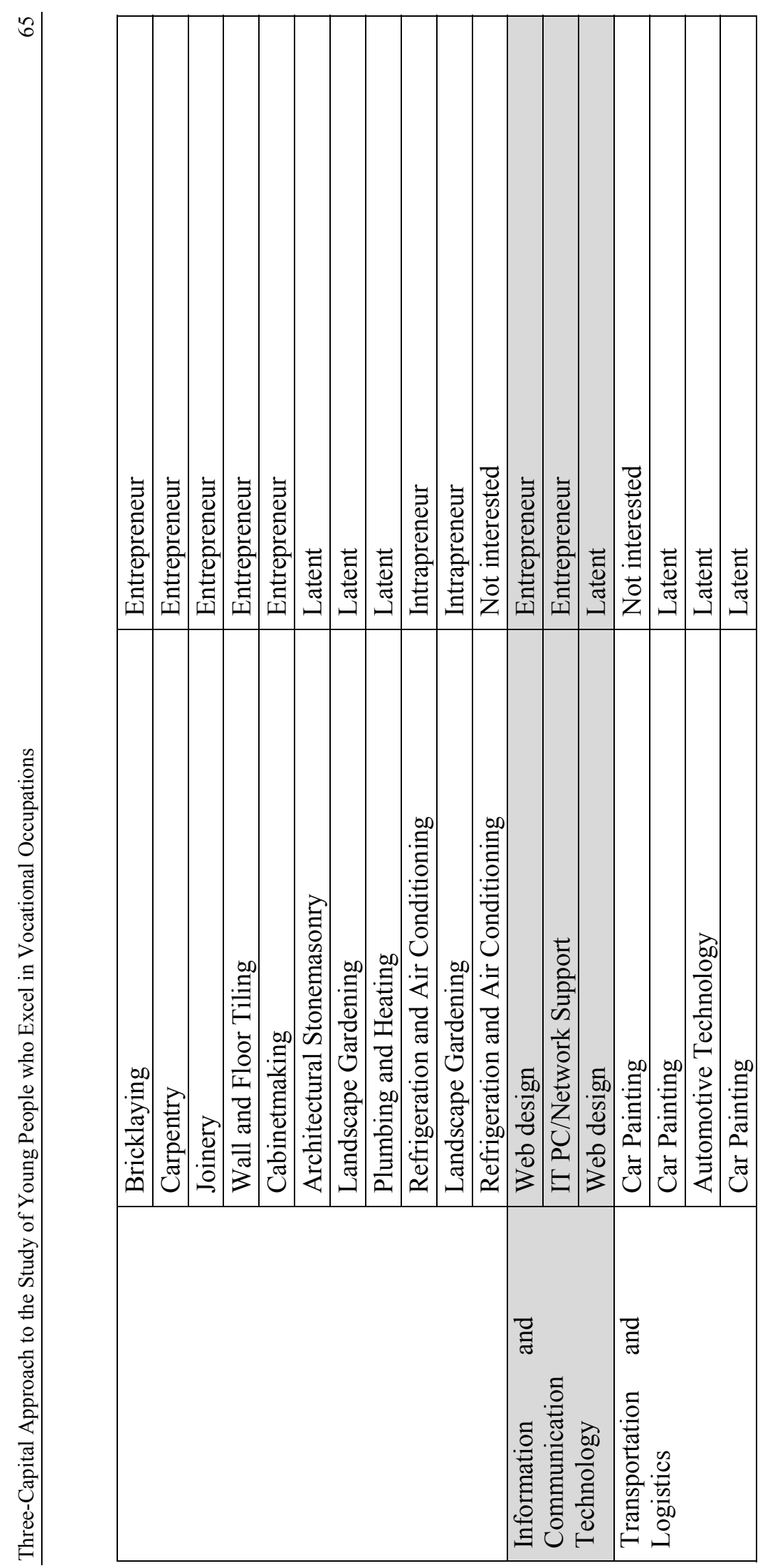

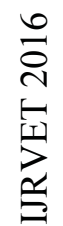

